\title{
Identification of tumor associated immune responses against brachyury, a transcription factor and driver of EMT, in chordoma patients receiving a yeast-brachyury vaccine (gi-6301)
}

\author{
Renee N Donahue ${ }^{1 *}$, Italia Grenga', Lauren Lepone ${ }^{1}$, James L Gulley², Christopher R Heery ${ }^{1}$, Ravi A Madan³, \\ Timothy C Rodell ${ }^{4}$, Jeffrey Schlom', Benedetto Farsaci ${ }^{1}$
}

From Society for Immunotherapy of Cancer 29th Annual Meeting

National Harbor, MD, USA. 6-9 November 2014

\section{Purpose}

Brachyury is a tumor-associated antigen and transcription factor that drives the epithelial-to-mesenchymal transition (EMT) in human carcinomas. The aim of this study was to assess whether patients with chordoma, a rare tumor of the notochord that over-expresses brachyury, can elicit a brachyury-specific $\mathrm{T}$ cell response following yeastBrachyury vaccination.

\begin{abstract}
Methods
An expansion cohort of 7 patients with chordoma, enrolled in the Phase I clinical trial "Open Label Study to Evaluate the Safety and Tolerability of GI-6301 (Whole Heat-Killed Recombinant yeast Modified to Express Brachyury Protein) in Adults with Solid Tumors", NCT01519817, were assessed for brachyury-specific T cell responses. Patients received 40 yeast units of vaccine every 2 weeks, and monthly dosing following restaging at day 85. PBMCs from pre- and post-vaccination were cultured in a 7-day in vitro stimulation (IVS) with overlapping 15-mer peptides of the brachyury protein that was encoded in the vaccine, and IL7/IL15. Following the IVS, cells were rested for 4 days, and then re-stimulated with 15-mer peptides. HLA 15-mers and a mixture of 9-mer to 15-mers of CMV, EBV, Flu, and Tetanus Toxin (CEFT) served as negative and positive controls, respectively. Brachyury-specific $\mathrm{T}$ cell responses were analyzed by flowcytometry intracellular staining (ICS) of CD4 and CD8 T
\end{abstract}

${ }^{1}$ Laboratory of Tumor Immunology and Biology, $\mathrm{CCR}, \mathrm{NCl}, \mathrm{NIH}$, Bethesda, MD, USA

Full list of author information is available at the end of the article lymphocytes for the cytokines IFN- $\gamma$, TNF, and IL-2, and the perforin/granzyme marker CD107a. Cells positive for $\geq 2$ cytokines were considered multipotent $\mathrm{T}$ lymphocytes, while cells co-expressing at least one cytokine and positive for CD107a were classified as having a cytokine/lysis association. A patient was considered an immune responder if, after brachyury 15-mer IVS, the frequency of T lymphocytes positive for a cytokine or CD107a postvaccine was $>50 \%$ compared to both (1) pre-vaccine values and (2) HLA control post-vaccine.

\section{Results}

$43 \%$ of patients (3/7) had a response to brachyury, with 2 having only a CD4 response, and 1 having both a CD4 and CD8 response. Of the 3 immune responders, 1 had only a single cytokine response, 1 had multipotent $\mathrm{T}$ lymphocytes, and 1 had a cytokine/lysis association.

\section{Conclusions}

These findings show for the first time that chordoma patients immunized with brachyury, a tumor associated antigen and transcription factors that drives EMT, can develop a brachyury-specific $\mathrm{T}$ cell immune response. These results warrant further studies using this vaccine in additional chordoma patients.

\section{Authors' details}

'Laboratory of Tumor Immunology and Biology, CCR, NCl, NIH, Bethesda, $\mathrm{MD}$, USA. ${ }^{2} \mathrm{CCR}, \mathrm{NCl}, \mathrm{NIH}$, Bethesda, MD, USA. ${ }^{3}$ Genitourinary Malignancies Branch, CCR, NCl, NIH, Bethesda, MD, USA. ${ }^{4}$ Globelmmune, Inc, Louisville, KY, USA. 
doi:10.1186/2051-1426-2-S3-P148

Cite this article as: Donahue et al:: Identification of tumor associated immune responses against brachyury, a transcription factor and driver of EMT, in chordoma patients receiving a yeast-brachyury vaccine (gi-6301). Journal for ImmunoTherapy of Cancer 2014 2(Suppl 3):P148.

Submit your next manuscript to BioMed Central and take full advantage of:

- Convenient online submission

- Thorough peer review

- No space constraints or color figure charges

- Immediate publication on acceptance

- Inclusion in PubMed, CAS, Scopus and Google Scholar

- Research which is freely available for redistribution

Submit your manuscript at www.biomedcentral.com/submit
C Biomed Central 